\title{
TOTAL QUALITY MANAJEMEN UNTUK PENINGKATAN MUTU MADRASAH
}

\author{
Tedi Priatna \\ Yayasan Amal Bakti Gombong Layang Cipadung \\ JI. AH. Nasution No. 37, Cipadung, Kota Bandung, Jawa Barat, 40614 \\ Email: tedipriatna2018@gmail.com
}

\begin{abstract}
ABSTRAK
Fokus utama naskah ini adalah gagasan tentang penterapan Total Quality Manajemen untuk peningaktan mutu madrasah. Pembahasan menggunakan analitis kritis sebagai pengembangan dari metode deskriptif. Objek kajian adalah gagasan atau ide. Teknik pengumpulan data yang digunakan adalah book survey atau library research. Hasil pembahasan menunjukkan bahwa banyak hal yang harus dilakukan untuk meningkatkan kualitas madrasah, salah satunya melalui penterapan manajerial berbasis peningkatan mutu. Implementasi Total Quality Manajemen untuk peningkatan mutu madrasah dapat diidentifikasi dari karakteristik TQM di madrasah meliputi Efektifitas proses belajar mengajar tinggi; kepemimpinan madrasah kuat; pengelolaan tenaga kependidikan yang efektif; madrasah memiliki budaya mutu; madrasah memiliki teamwork yang kompak, cerdas dan dinamis; madrasah memiliki kemandirian; partisipasi warga madrasah; madrasah memiliki transparansi menejemen; madrasah memiliki kemauan untuk berkembang; madrasah melakukan evaluasi dan perbaikan secara berkelanjutan; madrasah responsip dan antisipatif terhadap kebutuhan; madrasah memiliki akuntabilitas. Adapun strategi penterapan TQM di madrasah dapat diidentifikasi melalui kesatuan tujuan, concern pada kualitas, fokus pada peserta didik, komitmen jangka panjang, kerjasama tim (teamwork), perbaikan sistem secara berkesinambungan dan adanya pelibatan dan pemberdayaan seluruh SDM.
\end{abstract}

KATA KUNCI : Total Quality Manajemen, Madrasah.

\section{ABSTRACT}

The main focus of this manuscript is the idea of applying Total Quality Management to improve madrasah quality. Discussion using critical analytics as the development of descriptive methods. The object of study is an idea or idea. Data collection techniques used are book surveys or library research. The results of the discussion show that there are many things that must be done to improve the quality of madrasas, one of which is through managerial based quality improvement. Implementation of Total Quality Management to improve the quality of madrasas can be identified from the characteristics of TQM in madrasah including the effectiveness of high teaching and learning processes; 
strong madrasa leadership; effective management of education staff; madrasas have a quality culture; madrasas have a compact, smart and dynamic teamwork; madrassas have independence; Madrasah participation; madrasas have management transparency; madrasah have the will to develop; madrasas carry out continuous evaluation and improvement; madrasah responsive and anticipatory to needs; madrasas have accountability. The TQM implementation strategy in madrasah can be identified through unity of purpose, concern for quality, focus on students, long-term commitment, teamwork (continuous teamwork), continuous improvement of the system and the involvement and empowerment of all human resources.

Key Words: Total Quality Management, Madrasah.

\section{INTRODUCTION}

Dewasa ini ketika bangsa Indonesia sedang menjalani era pasca reformasi, ada banyak hal yang patut direnungkan berkenaan dengan realitas penyelenggaraan pendidikan di madrasah. Dengan mengacu pada akar kesejarahannya, Tilaar mengidentifikasi hal tersebut sebagai berikut : (a) Pendidikan Islam termasuk madrasah termarginalisasi dari arus modernisasi. Meskipun keadaan tersebut tidak selamanya bersifat negatif, namun hal itu telah membawa madrasah cenderung bersifat tertutup dan ortodok. (b) Karena pernah mengalami sifat diskriminatif dari pemerintah Belanda, pendidikan Islam (madrasah) terdorong menjadi milik rakyat pinggiran/ pedesaan. Madrasah memiliki konotasi pendidikan 'kampungan' yang berarti keterbelakangan. (c) Isi pendidikan cenderung berorientasi pada praktek-praktek ritual keagamaan yang kurang memperhatikan perkembangan ilmu pengetahuan dan teknologi. (d) Mengalami kelemahan manajemen karena sifatnya yang tertutup dan tidak berorientasi ke luar (H. A. R. Tilaar, 2000, h. 169).

Memang benar, pengakuan yuridis formal penyelenggaraan sistem pendidikan Madrasah, ternyata tidak cukup mengakibatkan mutu dan kualitas madrasah meningkat dengan sendirinya. Terintegrasinya madrasah dalam sistem pendidikan nasional, berkonsekwensi logis terjadinya banyak perubahan bahkan ekses terhadap segenap hal ihwal penyelenggaraan madrasah. Kendala, tantangan dan sekian problematika mengiringi perkembangan madrasah, dan hal tersebut kerap kali mengemuka hingga saat ini.

Pola pembinaan kelembagaan pendidikan yang dilakukan pemerintah melalui kementerian Pendidikan Nasional dan kemenetrian Agama, dimana madrasah merupakan salah satu binaan kementerian Agama mengesankan dan bahkan menegaskan kebijakan pendidikan masih dualistis. Dan oleh karenanya, harus diakui bahwa pola tersebut masih dan selalu menyimpan banyak persoalan. Di antara persoalan yang muncul adalah bahwa kementerian Agama sendiri nampak sangat kewalahan dalam memberikan pelayanan dan pembinaan madrasah yang maksimal. Prioritas target binaan kementerian Agama pada Madrasah Negeri ternyata belum menyentuh arah pendidikan Madrasah yang mengakibatkan menaiknya kualitas madrasah secara umum.

Hal ini diakibatkan karena madrasah negeri secara kuantitatif lebih kecil jumlahnya dibandingkan madrasah swasta, dan penyebaran madrasah negeri pun ternyata tidak merata. Berdasarkan data terakhir, jumlah madrasah negeri 
hanya 25,45 \% jumlah keseluruhan madrasah di Indonesia. Sedangkan 74,56 $\%$ madrasah swasta belum mendapat perhatian dan pembinaan sepenuhnya dari kementerian Agama.

Sistem pendidikan yang dikhotomik ternyata tidak saja muncul dalam pengelolaan kelembagaan madrasah, tetapi juga pada aspek kurikulum. Pada aspek kurikulum, sebenarnya persoalan tidak saja terjadi di madrasah tapi juga pada seluruh jenis pendidikan dalam sistem pendidikan nasional. Hal tersebut lebih dilematis terjadi pada dunia madrasah. Pada satu sisi karena statusnya madrasah harus menampilkan diri sebagai sekolah berciri khas Islam dengan ciri (a) Penjabaran mata pelajaran Pendidikan Agama Islam menjadi lima mata pelajaran, yaitu: al-Qur'an, Hadits, Fiqh, Aqidah Akhlak, Sejarah Kebudayaan Islam dan Bahasa Arab; (b) Penciptaan suasana keagamaan, antara lain meliputi: Suasana kehidupan madrasah yang agamis; Adanya sarana ibadah; dan Penggunaan metode pendekatan yang agamis dalam penyajian mata pelajaran yang memungkinkan; dan (c) Kualifikasi guru, antara lain guru madrasah harus beragama Islam dan berakhlak mulia (Husni Rahim, 2001 : 119). Pada sisi lain sebagai bagian dari Sistem Pendidikan Nasional, maka kurikulum madrasah sepenuhnya harus mengacu pada kurikulum 'Diknas'. Kondisi ini tentu saja dirasakan sangat berat oleh madrasah, apalagi karena alokasi jam pelajaran diproporsikan secara tidak seimbang. Walhasil, dalam bidang pengetahuan umum, madrasah sangat ketinggalan dibanding sekolah umum, dan dalam bidang pengetahuan agama, madrasah lebih mengorientasikan dirinya pada studi klasik keagamaan.

Selain itu pula, seperti yang dikemukakan Tilaar, kelemahan manajemen madrasah merupakan pekerjaan rumah yang harus segera diselesaikan. Manajemen pengelolaan madrasah masih tertutup dan konvensional, sementara tuntutan dan harapan masyarakat terhadap mutu madrasah sangat tinggi. Dalam konteks ini, diskursus yang akan dikemukakan pada tulisan ini berusaha melihat keberadaan madrasah sebagai lembaga yang dalam rentang waktu cukup panjang telah memainkan peran tersendiri dalam realitas pendidikan bangsa Indonesia, terutama dari aspek manajemennya.

\section{KAJIAN TEORI}

Manajemen adalah serangkain kegiatan berupa : merencanakan, mengorganisir, menggerakkan dan mengawasi, yang dilaksanakan sebagai acuan dalam mencapai tujuan melalaui strategi pencapaian sasaran yang ditentukan dengan cara pemanfaatan SDM serta pendukung sumber lain (George R.Terry 2006: 3 ). Kata dasar Peningkatan adalah tingkat dengan menambahkan kata imbuhan pe-an yang memiliki arti cara atau proses bagaimana meningkatkan. Mutu memiliki arti derajat (tingkat) kualitas produk baik berbentuk jasa maupun barang, berupa hal yang nyata ataupun yang tidak nyata.

Sallis dalam Thomas berpendapat bahwa: Kebutuhan dan keinginan dari pelanggan yang dapat diwujudkan oleh produsen memiliki makna sebagai Mutu yang dicapai. Standar isi, standar kompetensi lulusan, standar proses, standar pembiayaan, standar pengelolaan, standar sarana prasarana, standar penilaian pendidikan yang tertuang dalam Standar Nasional Pendidikan No. 32 Tahun 
2013, tugas peningkatan mutu adalah melebihi standar yang telah ditetapkan (Sallis, 2012, h. 71).

Pendidikan merupakan salah satu jenis layanan jasa memiliki indikator mutu berdasarkan pada pengguna merasa puas, performance, stimulus-respon, kepercayan dan rasa memiliki. Hal ini dapat dilihat dari bagaimana lembaga pendidikan melakukan peningkatan mutu dari berbagai komponen pendidikan berupa: kompetensi pendidik dan kependidikan, pemimpin lembaga, pelaksanan belajar mengar, sarana dan prasarana, penerapan kurikulum, penilain dan pengawasan, manajemen lembaga pembelajaran mutu lulusan, kualitas guru, kepala sekolah, staf sekolah, proses pembelajaran sarana dan prasarana, pengelolaan sekolah, implementasi kurikulum, sistem penilaian, serta penguatan kompentensi lulusan. Ini berarti melalui pengawasan harus terlihat dampaknya terhadap kinerja sekolah dalam meningkatkan mutu pendidikan. Hal ini dilakukan melalui penerapan standar mutu dengan melakukan continuous improvement, dengan pengawasan yang memadai

Peningkatan kualitas dalam mutu pendidikan dipengaruhi oleh raw input dan proses pelaksanaan manajemen pendidikan itu sendiri. Masukan dalam pendidikan berhubungan dengan dengan ketersedian sarana dan prasarana yang dibutuhkan oleh proses pelaksanaan pendidikan. Masukan dalam pendidikan seyogya berdasar pada probable input lembaga pendidikan sebelumnya, sehingga kualitas masukan sangat memadai. Selain faktor input, faktor yang mempengaruhi kualitas/mutu pendidikan ialah proses manajerial. Hadis dan Nurhayati (2010, h. 100-101), menyebutkan bahwa terdapat dua faktor penting yang dapat mempengaruhi mutu proses pembelajaran, faktor eksternal serta internal. Faktor eksternal adalah keseluruhan faktor diluar manajerial baik administrasi maupun pembelajaran dalam lembaga pendidikan. Sedangkan faktor internal yaitu : sosiologis, psikologis, dan fisiologis yang terdapat pada pengelola lembaga.

Edward Sallis menyatakan bahwa konsep absolut dan relatif tertera pada sebuah mutu. Akan tetapi pada saat ini konsep absolut tersemat pada pada mutu. Disebakan mutu memiliki makna kebaikan, keindahan, dan kebenaran; atau keselaran tanpa kompromi. Standar mutu terbagi menjadi dua; mutu yang berdasar pada standar jasa/produk; dan mutu berdasar pada customer. Mutu jasa/produk, memiliki kualifikasi: 1) berdasarkan spesifikasi, 2) berdasarkan pada tujuan serta manfaat, 3) tidak terdapat kesalahan dan pembuatan atau cacat, serta 4) tepat pembuatan pada awal dan seterusnya. Sedangkan kualitas yang bersandar pada customer, yaitu; 1) costomer satisfaction, 2 lebih dari ekspektasi customer, dan 3) membahagiakan customer.

Produk berbasis pada jasa mempunyai disilaritas dengan barang. Produk berdasarkan pada jasa mempunyai syarat sebagai berikut (Sallis, 2012, h. 63) :

1. Penerima jasa dan pemberi melalui proses kontak secara langsung.

2. Elemen kualitas jasa ditentukan oleh waktu.

3. Pelanggan menerima langsung barang jasa apabila terdapat "cacat" hal tersebut tidak diperbaiki.

4. Bentuk dan mutu nampak dan nyata.

5. Produktifitas dan output-nya susah diukur tingkat keberhasilannya

6. Indikator utamnya adalah kepuasan. 
Oleh sebab itu, kualitas jasa yang didapat oleh peserta didik, orang tua, masyarakat yang diberikan oleh lembaga pendidikan beruapa adalah pembelajaran, pengawasan dan penilaian serta sistem manajerial yang baik harus melaui standar opersional prosedur yang jelas dan bermutu tinggi.

\section{METHODOLOGY}

Paparan kertas kerja ini akan menggunakan metode "analitis kritis". Metode ini merupakan pengembangan dari metode deskriptif, yakni mendeskripsikan gagasan manusia tentang objek tertentu. Objek kajian dalam metode ini adalah gagasan atau ide manusia yang terungkap dalam bentuk media cetak, baik berupa naskah primer atau naskah sekunder. Gagasan dalam naskah primer ialah sejumlah data/fakta mengenai masalah pokok, sedangkan gagasan sekunder adalah pembahasan dan kritik terhadap gagasan primer. Tujuan analitis kritis ialah menganalis gagasan primer perihal ruang lingkup fakta dan permasalahan yang dijadikan sebagai fokus penelitian. Adapun fokusnya adalah (a) mendeskripsikan, (b) membahas, dan (c) mengkritik gagasan primer dan selanjutnya (d) melakukan studi analitik dengan mengembangkan studi yang berupa perbandingan, hubungan, pengembangan model rasional (Jujun S. Suriasumantri, 1998, h. 41-61). Teknik pengumpulan data yang digunakan adalah book survey atau library research.

Kertas kerja ini secara sistimatis terlebih dahulu akan mengemukakan abstraksi dan tahapan kesejarahan bagaimana madrasah menjadi bagian dari sistem pendidikan Nasional. Di akhir tulisan dengan melihat konteks dinamikanya dengan kondisi sosio kultural bangsa Indonesia yang terus berubah, tulisan ini mencoba mengidentifikasi problematika manajerial yang dihadapi madrasah dan mengajukan alternatif pemecahannya melalui Total Quality Manajemen (TQM).

\section{HASIL DAN PEMBAHASAN}

\section{Kelembagaan Pendidikan}

Mengkaji persoalan pendidikan tentunya mengkaji persoalan kebudayaan juga. Terlebih secara detai kajian pendidikan akan sampai pada pembicaraan wilayah penciptaan peradaban di masa yang akan datang. Bagaimanapun pendidikan pada dasarnya merupakan cara merekonstruksi pengalaman-pengalaman peradaban umat manusia terus-menerus sebagai fungsi menjalankan tugas kehidupannya, dari generasi ke generasi. Di sinilah Langgulung memandang makna pendidikan dari salah satu fungsi pendidikan itu sendiri, yaitu: (a) berdasar pda persepsi masyarakat, pendidikan adalah cara bagaimana mewariskan kebudayaan yang telah diperbuat generasi tua yang diturunkan kepada kepada generasi muda, supaya hidup dan tatanan kehidupan dapat terus-menerus berjalan. (b) berdasarkan pada kebutuhan individu, pendidikan dimaknai sebagai cara mengembangkan potensi yang tidak nampat dan bakat dimiliki manusia (Hasan Langgulung, 1992 : 3).

Secara sistemik, ikhtiar merekontruksi pengalaman dalam proses pengembangan kualitas individu melahirkan format sistem pendidikan. Sedangkan untuk memahami sistem pendidikan tersebut paling tidak dapat 
diidentifikasi berdasarkan pada dua sisi, yaitu berdasar pada proses dan kelembagaan (A. Malik Fadjar 1998 : 16).

Kelembagaan dalam penyelenggaraan pendidikan merupakan bagian dari sub sistem melakukan proses pelaksanaan pendidikan yang dapat menyelenggarakan proses dengan konsisten dan berkelanjutan. Adanya kelembagaan pendidikan merupakan conditio sine quo non (syarat mutlak) dalam proses pembudayaan umat manusia. la memiliki beban kultural edukatif terhadap perkembangan anak didik serta masyarakatnya (H.M. Arifin, 1994, h. 39).

Secara sosiologis, makna lembaga dapat dilihat dari pelbagai perspektif. (a) lembaga bermakna sebagai wahana pemenuhan kebutuhan pokok yang dapat melahirkan sistem yang stabil dan universal. (b) lembaga dapat berarti juga peraturan-peraturan atau cara-cara untuk mengatur pelaksanaan kepentingan anggota-anggota masyarakat dan hubungannya dengan yang lain. (Abu Ahmadi \& Nur Uhbiyati, 1991, h. 59. (c) lembaga berarti juga aturan yang menyatu ke dalam fungsi dari masyarakat menjadi sangat penting. Jadi ada yang berlandaskan pada budaya berupa nilai-nilai dan norma-norma, juga pada sisi strukturalnya berupa jenis peranan sosial, sehingga dalam kelembagaannya tidak lepas dari lembaga-lembaga sosial yang ada.

Lembaga sering juga disebut sebagai institusi; pranata; dan sistem norma yang mengatur aktifitas masyarakat pada aspek tertentu. Yudhistira mengungkapkan bahwa istilah institusi menunjukkan pola tingkah laku yang telah disepakati, karena itu institusi merupakan cara yang standar untuk mengatasi berbagai masalah masyarakat. Bagi $\mathrm{C}$. $\mathrm{H}$. Page, institusi adalah established forms or condition of procedure charac-teristics or group activity, misalnya sembahyang dan bentuk-bentuk pemujaan, pemogokan, dan tawarmenawar secara kolektif. Adapun berkenaan dengan istilah lembaga sosial, menurut Hendro Puspito berarti satu bentuk organisasi yang teratur dalam membentuk ikatan antar individu berdarkan pada pemilik otoritas formal dan hukum, sebagai dasar pencapaian kebutuhan sosial yang sangat mendasar.

Dalam kaitannya dengan istilah pendidikan, kelembagaan pendidikan dapat diartikan sebagai formulasi organisasi yang diadakan dalam rangka memajukan pendidikan, berdasar pada formulasi yang dibentuk sebagai pelaksana fungsinya, dan memiliki struktur yang khas, yang mampu membentuk ikatan antar individu, yang hal ini dapat membetuk lembaga berkekuatan hukum. Bronislaw Malinowski menganggap institusi merupakan konsep utama dalam memahami masyarakat, yang setiap institusi memiliki keterkaitan dan masing-masing memiliki fungsinya; institusi pendidikan adalah berfungsi mendidik seluruh anggota sebuah kelompok dan melanggengkan budaya yang diwariskan oleh generasi sebelumnya dalam berkehidupan di masyarakat (C. H. Page, 1969, h. 47-48).

Dalam tradisi Islam, sejarah telah memperlihatkan varian atas implementasi model kelembagaan pendidikannya. Bentuk institusi pendidikan seperti masjid (Surau, langgar, mushola), Madrasah dan pesantren (Kuttab), pengajian dan majlis ta'lim, atau yang lainnya menjadi ciri khas sebagai lembaga pendidikan Islam. 


\section{Madrasah: Selintas Sejarah Masuknya ke Indonesia}

Organisasi (institusi) dalam dunia pendidikan Islam (baca: klasik) berkembang sesuai dengan irama sejarah Islam itu sendiri. Bukan hanya dalam kualitas, tetapi fluktuasi sejarah telah merefleksikan pertumbuhan institusi (organisasi) pendidikan Islam secara kuantitatif. Masjid, kuttab, masjid khan dan madrasah atau yang lainnya telah merenda sejarah pendidikan Islam klasik. Lembaga-lembaga itulah secara sederhana mewakili organisasi pendidikan Islam masa itu. Secara sederhana, term kuttab (jamak: katatib) dan maktab merupakan sebutan untuk tempat belajar anak-anak setingkat sekolah dasar. Kuttab merupakan tempat belajar tulis-baca anak-anak, biasanya berlokasi di rumah-rumah guru (mu'alim atau mu'addib) atau di pekarangan sekitar masjid. Masjid khan adalah masjid yang dilengkapi dengan asrama bagi siswanya (khan = asrama, hotel, atau sejenis penginapan). Masjid khan berbeda dengan masjid pada umumnya, karena masjid khan dibangun sebagai lembaga pendidikan tinggi (Maksum, 1999, h. 56-57).

Munculnya berbagai pendidikan tersebut tidaklah bersamaan disebabkan lembaga pendidikan itu muncul berada ditengah-tengah kebutuhan masyarakat dan perkembangan zaman. Munculnya madrasah, sebagai pemecahan masalah akan keperluan dunia pendidikan ketika masih dilaksanakan di mesjid karena mengganggu kekhusuan peribadatan. Dengan munculnya fenomena madrasah, tidak berarti masjid sebagai sentra pendidikan menjadi terhenti.

Madrasah sebagai sistem pengajaran dan pendidikan berawal dari kumulasi dari tranformasi pembelajaran yang dilaksanakan di masjid. Perubahan dan perkembangan madrasah berlangsung secara bertahap yang kemudian berevolusi menjadi sistem yang berbasis kelas. Pembelajaran berbasis kitab perlahan mulai ditambah bahkan dirubah dengan basis materimateri tertentu. Sementara itu, penguasaan materi pelajaran masih menjadi dasar kenaikan tingkat. Transformasi madrasah dari masjid, hal ini didasarkan pada teori, yang dikemukakan oleh George Makdisi. Fokus kajiannya pada madrasah Nizamiyah. Teori yang diajukan Masidi, perkembangan pertama madrasah berdasarkan tiga: Tahap masjid, tahap masjid khan, dan tahap madrasah.

Di Indonesia, tidak diketahui secara pasti kapan istilah madrasah pertama kali digunakan untuk menunjuk sebuah institusi pendidikan. Hanya saja melihat perkembangannya, dipahami bahwa madrasah bukanlah sesuatu yang indegenous (pribumi) dalam peta dunia pendidikan di Indonesia. Sebagaimana ditunjukkan oleh istilah madrasah itu sendiri.

Berdarkan literal bahasa Arab, kata madrasah berarti tempat belajar (Bisri \& A. Fatah, 1999, h. 193). Sekolah merupakan padanan kata dalam bahasa Indonesia dari madrasah. Dalam Shorter Encyclopedia of Islam, istilah madrasah diartikan sebagai sebuah nama dari lembaga pendidikan yang mengajarkan pengetahuan Islam (H.A.R. Gibb \& Kramers, 1981, h. 300). Tempat proses pembelajaran atau tempat anak-anak belajar adalah madrasah. Hal ini mengambarkan bahwa proses belajar mengajar yang dilaksanakan di madrasah tidak jauh berbeda dengan proses pembelajaran yang dilakukan di sekolah.

Perbedaan yang ada dalam proses pendidikan yang dilakukan di madrasah lebih besar pada materi pengetahuan agama. Hal ini yang menjadi 
dasar peyebutan madrasah menjadi sekolah Agama (A. Malik Fadjar, 1998). Dalam hal ini, Haidar Putra Daulay mengemukakan: Berbeda dengan madrasah di dunia Arab, nama lembaga ini menjadi nama yang umum dipergunakan sebagai tempat pembelajaran secara umum, berbeda dengan yang terjadi di Indonesia ditujukan (Haidar Putra Daulay, 2001, h. 59).

Kemunculan madrasah pada awal abad ke-20 merupakan fenomena modern sebagai tradisi pendidikan bagi orang-orang Islam di Indonesia. Awal mula transformasi kelembagaan pendidikan dan pembelajaran Islam di Indonesia berasal dari lembaga pendidikan pesantren, madrasah dan kemudian sekolah. Pendidikan pesantren dan surau berkembang menjadi madrasah di Indonesia (Maksum, 1999, h. 82-96).

Dalam telahaan atas pertumbuhan madrasah di Indonesia, diduga kuat ada dua faktor yang melatarbelakanginya. (a) Pertumbuhan madrasah sebenarnya merupakan respons pendidikan Islam terhadap sistem persekolahan yang sudah menjadi kebijakan pemerintah Hindia Belanda dalam kerangka politik etisnya. (b) pertumbuhan madrasah sebenarnya merupakan bagian dari gerakan pembaharuan Islam di Indonesia, yang memiliki kontak cukup intensif dengan gerakan pembaharuan di Timur Tengah (Maksum, 1999, h. 82-96).

Latar belakang awal munculnya pendidikan madrasah di Indonesia berdasarkan: (a) realisasi dan manifestasi perubahan regulasi pendidikan oleh Islam itu sendiri, (b) Upaya peningkatan penyempurnaan terhadap sistem pendidikan Masjid ke arah suatu sistem pendidikan yang lebih memungkinkan lulusannya memperoleh kesempatan yang sama dengan sekolah umum, misalnya masalah kesamaan kesempatan kerja dan perolehan ijazah, (c) Menjembatani antara sistem pendidikan tradisional dan sistem pendidikan modern dari hasil akulturasi, (d) Adanya sikap mental pada sementara golongan umat Islam, khususnya santri yang terpukau pada Barat sebagai sistem pen-didikan mereka. (Muhaimin \& Abdul Mujib, 1993, h. 305).

Pada saat ini madrasah terus melakukan pembenahan dan pengembangan baik kurikulum, pejenjangan studinya dan tujuannya. Hal ini dilakukan sebagai bagian dari menyelaraskan perubahan zaman serta kebutuhan masyarakat Indonesia. Dalam kehidupan berbangsa dan negara madrasah menjadi fenomena dalam berbudaya sebagai bentuk kelembagaan yang terus melakukan proses sosialisasi yang intensif. Hingga pada akhirnya secara perlahan namun pasti madrasah saat ini menjadi bagian dari sistem pendidikan Nasional.

Manajemen pembelajaran berbasis sistem madrasah bagian dari terobosan budaya yang awal individual melalui sistem sorogan dan wetonan. Model manajemen pembelajaran yang baru dengan menggunakan gaya, nampak memberikan warna tersendiri bagi perkembangan madrasah seperti; pembelajaran klasikal, pengetahuan Islam yang dikelompokan berdasar materi dan tingkatan, serta termasuk lama waktu pendidikan yang dibutuhkan.

Format dan model pendidikan madrasah seiringnya waktu nampak semakin jelas wujudnya. Harus diakui bahwa proses pengakuan, atau masuknya madrasah dalam sistem pendidikan nasional di Indonesia, ternyata melalui perjalanan yang sangat panjang dan melelahkan. Secara formal legal, umat Islam Indonesia mungkin baru merasa puas (?), ketika lahir Undang- 
Undang Sistem Pendidikan Nasional No. 2 tahun 1989 apalagi USPN tahun 2003. Berbeda dengan undang-undang sebelumnya, UUSPN ini mengatur ketentuan penyelenggaraan pendidikan yang mencakup semua jalur dan jenis pendidikan, termasuk madrasah di dalamnya. A. Malik Fadjar mengungkapkan hal tersebut sebagai berikut: "Berdasarkan Undang-undang Nomor 2 tahun 1989 tentang Sistem Pendidikan Nasional, maka madrasah, sejak dari tingkat ibtidaiyah sampai dengan tingkat aliyah, ditempatkan dalam kedudukan yang sama dengan sekolah umum. Perbedaan terletak pada ciri khas Islam yang dikenakan kepada sistem madrasah. Ini tentu lebih mengukuhkan dasar filosofi untuk mengakomodasikan kepentingan keagamaan dengan kepentingan kewarganegaraan (1998, h. 33).

Melalui UUSPN Nomor 2 tahun 1989 dan USPN tahun 2003, madrasah oleh pemerintah ditempatkan secara proporsional menjadi bagian yang memiliki pengaruh yang signifikan dalam proses penyelenggaraan sistem pendidikan nasional. Suatu kenyataan dan sekaligus merupakan keunggulan bahwa sistem pendidikan nasional kemudian berhasil memperlihatkan daya akomodatifnya dalam mengintegrasikan pranata-pranata pendidikan yang beragam ke dalam bangunan sistemik pendidikan nasional, termasuk di dalamnya madrasah.

\section{Total Quality Manajemen Untuk Pengembangan Mutu Pendidikan}

Kompetesi yang sehat menjadi tuntutan bagi orang yang mau berkompetisi pada masyarakat yang berkembang secara kompetitif. Lembaga pendidikan harus mampu beradaptasi dengan perkembangan dalam rangka mewujudkan lembaga yang mengedapankan mutu serta proses manajerialnya, agar dapat menjadi lembaga yang kompetitif yang mampu merebut pasar. Pendekatan menejerial berbasis Total Quality Manajemen (TQM) menjadi sebuah keniscayaan yang harus dilakukan oleh lembaga pendidikan untuk meningkatkan kualitas.

Reorientasi dari organisasi adalah kualitas, hal ini merupakan Hakekat

Total Quality Management (TQM) atau manajemen kualitas terpadu berdasarkan pada nilai filosofi serta budaya (kerja) organisasi (phylosopy of management). Tujuan (goal) yang hendak digapai oleh organisasi dengan dengan cara mengedapankan budaya TQM berdasar pada pemenuhan atau melebihi berbagai kebutuhan (needs) dan yang diinginkan (desire) oleh customer (Marshal Sashkin dan Kisser, 1993, h. 75). TQM dimaknai pengelolaan berbasis kualitas seluruh komponen (stakehorder) yang memiliki kepentingan berbasis visi dan misi sebuah organisasi. Oleh karena itu, TQM bukanlah hanya sekedar pada aspek pemeriksaan atau pembebanan semata. Akan tetapi, TQM lebih dari sekedar usaha dalam melakukan segala sesuatu yang baik serta benar setiap waktu. TQM tidak sekedar bekerja untuk memenuhi agenda atau kebutuhan pihak lain, walaupun agenda atau kebutuhan itu dikhususkan bagi customer dan klien. TQM tidak hanya diperuntukkan bagi menajer senior serta yang kemudian menghindari tujuan yang telah ditentukan (Edward Sallis, 2006, h. 34-35).

Pengertian "total" dalam makna TQM ialah bagaimana seluruh komponen organisasi terlibat secara langsung dan terus-menerus. Sedangkan "manajemen" dalam TQM yaitu pengaturan setiap individu yang ada pada sebuah organisai, tidak memandang status, peran atau posisinya. Keseluruhan 
sumber daya adalah manajer yang memiliki tugas dan tanggung jawab masingmasing ${ }^{13}$. Hal ini selaras dengan definisi, Lesley dan Malcolm menyatakan bahwa TQM, seluruh fungsionaris organisasi, tanpa ada pengecualian diharuskan kemiliki tiga kompetensi, antara lain: (1), melakukan berbagai kegiatan yang baik dan benar. Memuaskan kebutuhan pelanggan menjadi core bisnis dalam seluruh kegiatan, yang dapat diterima. Program atau kegiatan yang tidak menunjang pada aspek tersebut menjadi tidak perlu sehingga jangan diteruskan lagi. (2), mengerjakan sesuatu dengan tepat. Hal Ini dimaknai bahwa seluruh program dan atau kegiatan dijalankan secara tepat, sehingga output kegiatan sesuai dengan keperluan pelanggan. (3) melakukan hal-hal dengan baik dan benar sejak awal pada setiap waktu. Mencegah kesalahan yang akan muncul sebagai landasan dan pemikiran pada setiap orientasi kerja. Asasnya, berdasar pada Lesley dan Malcolm, TQM adalah pendekatan yang dilakukan secara sistematis melalui perencanaan, dan pengelolaan aktivitas, yang memiliki motto: Do the right think, first time, every time, yaitu "kerjakan sesuatu yang benar dengan benar, sejak pertama kali, setiap waktu" (Edward Sallis, 2006, h. 34-35).

Goetsch dan Davis menyampaikan karakteristik kualitas manajemen: (a) investor, customer, dan tenaga kerja layak mendapatkan komitmen total pada peningkatan nilai secara kontinyu, (b) kepentingan customer menjadi dasar lembaga dalam meningkatkan kualitas dan dorongan pasar bukan hanya sekedar memenuhi kepentingan organisasi semata. dan (c) perbaikan dan komunikasi berkesinambungan menjadi komitmen yang harus dibangun oleh pimpinan. (Lesley Munro dan Malcolm, 2002, h. 7-8). Asas TQM ialah bagiamana dalam melangsungkan usahanya menggunakan pendekatan yang mencoba memaksimalkan daya jual lembaga melalui proses perbaikan yang berkesinambungan dalam membuat produk atau memberikan jasa, manusia, proses dan lingkungannya. Oleh sebab itu, TQM mempunyai karakteristik sebagai berikut : (a) pelanggan sebagai fokus utama, baik internal ataupun eksternal, (b) Kualitas yang tinggi menjadi obsesi, (c) pemecahan masalah dan pengambilan keputusan berdasarkan pendekatan ilmiah, (d) program jangka panjang berbasis komitmen, (e kerja sama tim menjadi landasan utama (teamwork), (f) proses diperbaiki secara terus-menerus (g) pendidikan serta pelatihan dilakukan dengan baik, (h) kebebasan diberikan berbasis terkendali, (i) tujuan menjadi dasar pelaksanaan kegiatan, (j) pelibatan dan pemberdayaan dilakukan secara merata (Goetsch, David L \& Stanley B. Davis, 2000, h. 69).

Ciptono F. dan Anastasia menerangkan bahwa TQM memiliki unsur pokok dan prinsip : (a) pelanggan harus mendapatkan kepuasan. Spesifikasispesifikasi yang sesuai tidak hanya menggambarkan kualitas, akan tetapi pelanggan internal serta eksternal merasakan manfaat dan kepuasaan ini yang dimaknai sebagai kualitas. Ketepatan waktu, keamanan, nilai materi merupakan keseluruhan aspek yang harus diberikan oleh produsen untuk kepuasan pelanggan. (b) Seluruh orang harus mendapatkan respek. Kreatifitas dan talenta yang unik selayaknya mendapatkan tersendiri di pada produsen. Jika demikian, maka sumber daya yang dimiliki organisasi akan memiliki makna serta memberikan dapat untuk perkembangan organisasi itu sendiri. Pengambilan keputusan dalam sebuah lembaga tidak bisa hanya dilakukan oleh puncak manajemen saja, tetapi perlu melibatkan dan memberikan 
kesempatan pada personil lembaga lainnya sebagai bentuk partisipasi dan pengembangan diri. (c) fakta menjadi dasar manajerial. Fakta menjadi orientasi lembaga dalam menjalankan organisasi. Hal ini data dan fakta menjadi dasar lembaga dalam pengambilan keputusan, tidak berdasarkan pada perasaan (feeling). Fakta memilki dua konsep yaitu; (a) prioritas, adalah konsep tentang bagaimana melakukan perbaikan berdasarkan prioritas utama tidak pada keseluruhan aspek secara serentak, karena keterbatasan SDM yang dimiliki oleh manajemen. Data menjadi sumber utama dalam menentukan prioritas dan hal ini yang menjadikan tim manajemen dapat fokus mengendalikan berbagai kemungkinan dan pada situasi apapun. (b) bervariatif, atau individu berkerja berdasarkan variabilitas. Variabilitas dalam bekerja, menjadi gambaran yang dimana sistem pada lembaga menuntut perubahan serta kinerja maksimal sebagai bagian dari pengembangan dan perubahan sistem. Tindakan dan keputusan yang dibuat oleh manajemen dapat diprediksi berdasarkan sistem yang dibuat. (d) berkesinambungannya perbaikan. Dilakukannya perbaikan yang terus menerus menjadi sangat penting bagi kemajuan lembaga.

\section{Implementasi Total Quality Manajemen untuk Peningkatan Mutu Madrasah}

Lembaga pendidikan dalam hal ini madrasah yang mewadahi seluruh ide budaya dan sosial agama warga muslim di Indonesia, secara kultural mengakar sangat kuat di dalam proses pendidikan di negara Republik Indonesia. Perjuangan umat Islam mengintegrasikan madrasah dalam Sistem Pendidikan Indonesia yang begitu panjang, namun demikian madrasah hingga sekarang masih memperlihatkan kualitas yang belum sepenuhnya memadai. Bentuk serta model pembinaan lembaga pendidikan masih mengesankan kebijakan pendidikan yang dualistis. Dan oleh karenanya, harus diakui bahwa pola tersebut masih dan selalu menyimpan banyak persoalan.

Madrasah-madrasah di Indonesia sekarang umumnya belum mampu menyelenggarakan pembelajaran dan pengelolaan sekolah yang efektif. Walaupun kuantitasnya terus mengalami perkembangan, lembaga pendidikan madrasah pada realitasnya belum menjadi pilihan pertama dan utama masyarakat. Sebagian masyarakat memang memilih Madrasah, tetapi alasan mereka memilih madrasah karena lembaga pendidikan tersebut menyelenggarakan pendidikan agama. Tetapi, masyarakat terkadang kecewa, karena hasil pendidikan agama tersebut sering masih belum sesuai dengan harapan.

Dari sisi penyelenggaraan madrasah, faktor manajerial memegang peranan penting untuk meningkatkan mutu pendidikan, dan pada faktor inilah nampak sekali kelemahan kualitas madrasah. Harus diakui bahwa salah satu faktor lemahnya kualitas madrasah adalah tidak adanya dukungan kualitas manajemen madrasah yang kapabel. Untuk itulah diperlukan program sistematis dan terrencana dalam upaya meningkatkan mutu manajerial pengelolaan madrasah. Hal ini tentu saja sangat relevan dengan prinsip management school based education yang bergulir seiring kebijakan otonomi daerah untuk meningkatkan mutu pendidikan nasional.

Otonomi pendidikan mendorong pemberlakuan dan pemberian kewenangan kepada institusi penyelenggara pendidikan untuk merancang, menyusun, melaksanakan program yang dibuat secara bersama-sama dan 
dilaksanakan secar bersama pula; keberhasilan otonomi pendidikan amat ditentukan salah satunya oleh Education Based Management yang diterapkan.

Pada pelaksanaan Education Based Management cukup berat konsekuensinya baik menyangkut menejemen, pembiayaan, sarana prasarana, sumber daya manusianya, kemampuan dan kemauan warga madrasah untuk meningkatkan mutu pendidikan, maka dipandang perlu penerapan Total Quality Management sebagai salah satu upaya untuk pemberdayaan SDM dan seluruh potensi di madrasah maupun di luar madrasah secara bersama-sama untuk memberikan jaminan kualitas penyelenggaraan sesuai dengan yang diharapkan.

Total Quality Management atau Manajemen Mutu Total adalah strategi yang berfokus pada pelanggan yang mendapatkan kepuasan dengan menyertakan semua anggota serta steakholder organisasi. Manajemen mutu terpadu berupaya meningkatkan mutu pendidikan yang bertujuan untuk memandirikan atau memberdayakan institusi yang berorientasi kepada kebutuhan pengguna.

Implementasi Total Quality Manajemen untuk peningkatan mutu madrasah dapat diidentifikasi dari karakteristik TQM di madrasah meliputi: (a) Output yang Diharapkan adalah kinerja madrasah, efektifitasnya, produktifitasnya, efisiensinya, inovasinya, dan moral kerjanya baik yang akademik maupun yang non akademik semua yang terlibat dalam pengembangan madrasah; (b) Proses. Efektifitas proses belajar mengajar tinggi; kepemimpinan madrasah kuat; manajemen tenaga kependidikan berdasarkan pada efektifitas; budaya mutu yang dikembangkan oleh madrasah; kekompakan teamwork dimiliki oleh madrasah, dinamis dan cerdas; madrasah memiliki kemandirian; warga madrasah aktif partisipasi; manajemen madrasah berasas transparan; keinginan yang kuat untuk berkembang; evaluasi serta perbaikan dilakukan madrasah terus-menerus; respons yang baik dari, adaptif dan pada perkembangan serta keperluan pengguna; tanggung jawab yang kuat dimiliki oleh; (c) Masukan Pendidikan. memiliki kebijakan kualitas; sumber daya yang memadai serta siap pakai; pengembangan yang mengarah pada prestasi tinggi; peserta didik menjadi fokus utama.

Adapun strategi penterapan TQM di madrasah dapat diidentifikasi melalui kesatuan tujuan, concern pada kualitas, fokus pada peserta didik, komitmen yang dibangun berdurasi waktu yang panjang, jalinan kerjasama yang dibagun dalam tim kuat (teamwork), sistem diperbaiki secara terus menerus dengan melibatkan dan memberdayakan seluruh SDM.

\section{SIMPULAN}

Upaya pengintegrasian madrasah dalam sistem pendidikan nasional, memperlihatkan sebuah pergumulan dan dinamika historis yang begitu berat. Oleh karenanya, mengaca pada sejarah tersebut, umat Islam Indonesia patut berbangga memiliki madrasah. Namun, kebanggaan tersebut nampaknya tidak akan berarti banyak kalau umat Islam hanya sekadar diam atas sejumlah tantangan dan kendala yang dihadapi madrasah dewasa ini. Banyak hal yang harus dilakukan terutama sekali adalah pencurahan perhatian yang lebih serius 
atas perkembangan madrasah dan terus meningkatkan kualitasnya, salah satunya melalui penterapan manajerial berbasis peningkatan mutu.

Implementasi Total Quality Manajemen untuk peningkatan mutu madrasah dapat diidentifikasi dari karakteristik TQM di madrasah meliputi Efektifitas proses belajar mengajar tinggi; kepemimpinan madrasah kuat; manajemen tenaga kependidikan berlandakan efektifitas; budaya mutu madrasah; kompaknya teamwork yang dimiliki oleh madrasah, dinamis dan cerdas; kemandirian yang dimiliki oleh madrasah; peran warga madrasah; manejemen madrasah yang transparan; madrasah memiliki keinginan untuk berkembang; perbaikan yang berkelanjutan oleh madrasah berdasarkan pada evaluasi; madrasah responsip dan adaptif terhadap keinginan dan kebutuhan pengguna; madrasah memiliki akuntabilitas. Adapun strategi penterapan TQM di madrasah dapat diidentifikasi melalui kesatuan tujuan, concern pada kualitas, fokus pada peserta didik, komitmen yang dilakukan berdurasi jangka panjang, kerjasama yang dibangun berdasarkan pada tim yang kuat (teamwork), sistem yang diperbaiki secara terus menerus dengan melibatkan seluruh SDM.

\section{REFERENSI}

Ahmadi, A, \& Nur Uhbiyati. (1991), IImu Pendidikan. Jakarta: Rineka Cipta.

Arifin, H.M. (1994). Filsafat Pendidikan Islam. Jakarta: Bumi Aksara..

Bisri, A, \& Fatah , M. A. (1999). Kamus al-Bisri: Indonesia - Arab. Arab Indonesia. Surabaya: Pustaka Progressif.

Daulay, H. P. (2001). Historisitas dan Eksistensi Pesantren. Sekolah dan Madrasah. Yogyakarta: Tiara Wacana.

Fadjar, A. M. (1998). Madrasah dan Tantangan Modernitas. Bandung: Mizan.

Gibb, H.A.R. \& Kramers. (1981). Shorter Encyclopaedia of Islam. Leiden: E.J. Brill.

Goetsch, D. L. \& Davis, S. B. (2000). Quality management: Introduction to Total Quality Management for Production, Processing, and Service, New Jersey: Prentice-Hall, Inc.

Hadis, A. \& N. (2010). Manajemen Mutu Pendidikan. Bandung.:Alfabeta

Langgulung, H. (1992). Asas-Asas Pendidikan Islam. cet. II. Jakarta: Pustaka al-Husna.

Maksum. (1999). Madrasah: Sejarah dan Perkembangannya. Jakarta: Logos Wacana IImu.

Muhaimin \& Mujib A. (1993). Pemikiran Pendidikan Islam. Jakarta: Trigenda karya.

Munro, L. \& Malcolm, (2002). Menerapkan Manajemen Mutu Terpadu, (Jakarta: PT Gramedia, (Terjemahan), Cet. ke-3.

Page , C. H. (1969). Society an Introductory Analysis. New York: Mcmilan.

Rahim, H. (2001). Arah Baru Pendidikan Islam di Indonesia. Cet. I. Jakarta: Logos Wacana Ilmu.

Sallis, E. (2006). Total Quality Managament In Education; Manajemen Mutu Pendidikan terj. Ahmad Ali Riyat, et.al., Yogyakarta : IRCiSoD, cet. IV

Sashkin, M \& Kisser, (1993). Putting Total Quality Management to Work, (San Francisco: Berret - Kohler Publisher.

Suriasumantri, J. S. (1998). Filsafat Ilmu: Sebuah Pengantar Populer. Jakarta: Pustaka Sinar Harapan. 
Tedi Priatna

Tafsir, A. "Pembaharuan Sistem. Pendidikan Nasional". dalam Mimbar Pendidikan. Bandung: Fakultas Tarbiyah. VOL. I/NO. 25/1998

Tilaar, H. A. R.. (2000). Paradigma Baru Pendidikan Nasional. Jakarta: Rineka Cipta.

Tjiptono, F. \& Diana, A. (2003). Total Quality Management, Yogyakarta: Andi Cet. ke-2. 